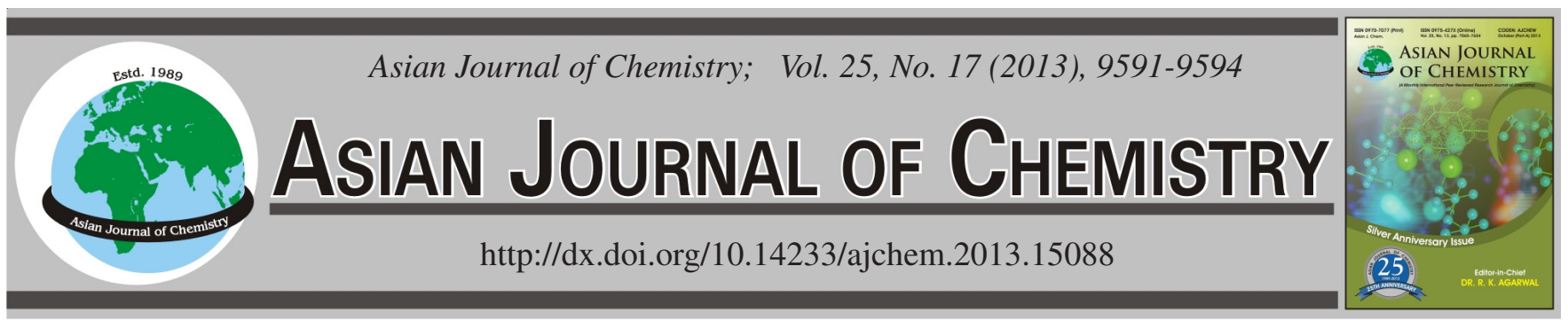

\title{
Removal of Ammonium Nitrogen from Petrochemical Wastewater by Anaerobic-Aerobic Process
}

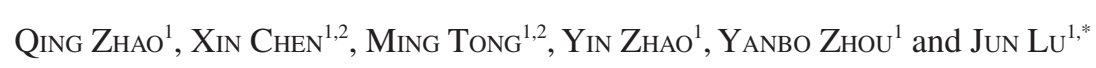

${ }^{1}$ Key Laboratory of Coal Gasification and Energy Chemical Engineering of Ministry of Education, East China University of Science and Technology, Shanghai 200237, P.R. China

${ }^{2}$ SINOPEC Ningbo Engineering Co. Ltd., Ningbo 315103, P.R. China

*Corresponding author: E-mail: lujun@ecust.edu.cn; zhaoqing10061261@126.com

(Received: 2 January 2013;

Accepted: 4 October 2013)

AJC-14234

Pilot equipment was set up to evaluate effectiveness of anaerobic-aerobic $(\mathrm{A} / \mathrm{O})$ process on removing ammonia nitrogen $\left(\mathrm{NH}_{3}-\mathrm{N}\right)$ from
petrochemical wastewater. The results showed that the anaerobic-aerobic process had a good biological degradation effect on $\mathrm{NH}_{3}-\mathrm{N}$ from
petrochemical wastewater. Effluent $\mathrm{NH}_{3}-\mathrm{N}$ was below $2 \mathrm{mg} / \mathrm{L}$ during steady operation, which can meet the petrochemical wastewater
discharge standards in China. The removal rate of $\mathrm{NH}_{3}-\mathrm{N}$ was nealy $100 \%$ with the influent $\mathrm{NH}_{3}-\mathrm{N}$ from $20-105 \mathrm{mg} / \mathrm{L}$. C/N ratio and $\mathrm{pH}$
value were the key factors on removal efficiency of nitrogen in the biosystem. The optimal experiment conditions were determined as
follows: $\mathrm{C} / \mathrm{N} \geq 5, \mathrm{pH}$ value $7-8$. The $\mathrm{NH}_{3}-\mathrm{N}$ biodegradation process can be described by Monod equation and the kinetics parameters
were $v_{\max }=0.12 \mathrm{~h}^{-1}, \mathrm{~K}_{\mathrm{S}}=7.22 \mathrm{mg} / \mathrm{L}$.

Key Words: Petrochemical wastewater, Anaerobic-aerobic process, Ammonia nitrogen, Kinetics.

\section{INTRODUCTION}

Petrochemical wastewater is generated from a wide variety of oil refining process and contains different complex components and high concentrations of pollutants. Uncontrolled disposal of these effluents can cause great damage to the environment. Nitrogen discharge to ponds and lakes could contribute to enhance the eutrophication process and damage aquatic life $\mathrm{e}^{1,2}$. For this reason, Chinese local government has developed restricted regulations. The new industrial wastewater discharge standards require that effluent $\mathrm{NH}_{3}-\mathrm{N}$ concentration must be less than $5 \mathrm{mg} / \mathrm{L}$. The new policy makes petrochemical wastewater treatment plants need to regulate their process or processing parameters to improve the denitrification efficiency. Qilu ethylene wastewater treatment plant is a branch of China Petroleum and Chemical Corporation. It undertakes the treatment task of wastewater from more than 40 petrochemical plants and chemical companies in Qilu ethylene area. In order to meet the new emission requirements, anaerobic-aerobic $(\mathrm{A} / \mathrm{O})$ process was used for removing organic compounds and nitrogen from the wastewater $^{3-5}$. The aim of this paper was to evaluate the treatment effectiveness of $\mathrm{A} / \mathrm{O}$ process on petrochemical wastewater and quantify the influence of influent $\mathrm{C} / \mathrm{N}$ ratio, $\mathrm{pH}$ value on removal efficiency of ammonium nitrogen in pilot equipment ${ }^{6,7}$, then applied the optimum condition to the wastewater treatment plant. In the meanwhile, set up the kinetics model of degradation of ammonium nitrogen by activated sludge in aerobic tank.
In the last decade, studies on biological removal of nitrogen using synthetic wastewater to simulate industrial discharges have been performed in order to evaluate the potential application of the $\mathrm{A} / \mathrm{O}$ process in industrial wastewaters treatment ${ }^{8}$, but few studies focused on real industrial wastewater have been published in the petrochemical industry. In this study, the performance of pilot equipment fed with real petrochemical wastewater from wastewater treatment plant was measured at different conditions. Based on the experimental results, kinetic coefficients of degradation of ammonium nitrogen were determined, which might provide the basic design criteria required for operating the wastewater treatment plant ${ }^{9,10}$.

\section{EXPERIMENTAL}

The pilot equipment consists of an anaerobic tank (1.2 $\left.\mathrm{m}^{3}\right)$, an aerobic tank $\left(2.4 \mathrm{~m}^{3}\right)$ and a secondary sedimentation $\operatorname{tank}\left(0.75 \mathrm{~m}^{3}\right)$, as shown in Fig. 1. Anaerobic tank and aerobic tank are the main reactors in this study.

During the experiment, these reactors were fed continuously with petrochemical wastewater from the preliminary sedimentation tank in the site, at flow rates of $120 \mathrm{~L} / \mathrm{h}$.

The source of inoculation activated sludge was obtained from the sludge mixed liquor in aerobic tank of wastewater treatment plant. The composition of wastewater is given in Table-1. Temperature was controlled to be $20-25^{\circ} \mathrm{C}$, hydraulic retention time (HRT) of anaerobic and aerobic tank was 9.2 and $19.1 \mathrm{~h}$, respectively. The mixed liquor suspended solid 


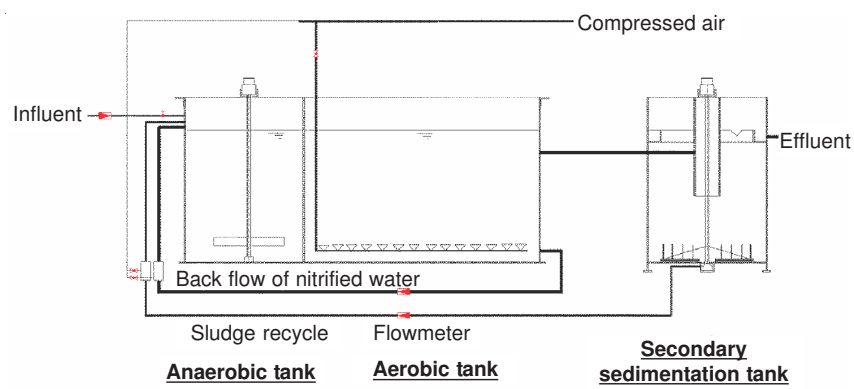

Fig. 1. Schematic diagram of the pilot equipment

\begin{tabular}{cccccc}
\multicolumn{7}{c}{ TABLE-1 } \\
COMPOSITION OF PETROCHEMICAL WASTEWATER \\
\hline & $\mathrm{pH}$ & $\begin{array}{c}\mathrm{COD} \\
(\mathrm{mg} / \mathrm{L})\end{array}$ & $\begin{array}{c}\mathrm{BOD}_{5} \\
(\mathrm{mg} / \mathrm{L})\end{array}$ & $\begin{array}{c}\mathrm{SS} \\
(\mathrm{mg} / \mathrm{L})\end{array}$ & $\begin{array}{c}\mathrm{NH}_{3}-\mathrm{N} \\
(\mathrm{mg} / \mathrm{L})\end{array}$ \\
\hline $\begin{array}{c}\text { Influent } \\
\text { Effluent emission }\end{array}$ & $6-9$ & $170-360$ & $\leq 290$ & $\leq 100$ & $20-70$ \\
& $6-9$ & $\leq 50$ & $\leq 20$ & $\leq 70$ & $\leq 5$ \\
\hline
\end{tabular}

concentration (MLSS), mixed liquor volatile suspended solids concentration (MLVSS), dissolved oxygen (DO) concentration in aerobic tank were maintained at 7000-8000, 3500-4700 and $4 \mathrm{mg} / \mathrm{L}$.

Experiments were carried out in two phases. In the first stage, the reactors were operated for 10 days until the MLVSS, effluent chemical oxygen demand (COD) concentration and sludge properties reached a steady state. Influent $\mathrm{NH}_{3}-\mathrm{N}$ concentration in wastewater treatment plant swings from 20$70 \mathrm{mg} / \mathrm{L}$. Durning the steady continuous operation, ammonium sulfate was added to real petrochemical wastewater to regulate influent $\mathrm{NH}_{3}-\mathrm{N}$ concentration from 20-105 mg/L, pilot experiments were designed to evaluate the process behaviour (maximum $\mathrm{NH}_{3}-\mathrm{N}$ loading, transient responses, etc.) in high influent $\mathrm{NH}_{3}-\mathrm{N}$ concentration condition.

In the second stage, experimental conditions were changed in order to determine the optimum operation conditions for denitrification of petrochemical wastewater. At the same time, the kinetics of degradation of $\mathrm{NH}_{3}-\mathrm{N}$ by $\mathrm{A} / \mathrm{O}$ process was studied, which can be a theoretical foundation for optimization and monitoring of $\mathrm{A} / \mathrm{O}$ process in wastewater treatment plant.

Detection method: Analyses of mixed liquor volatile suspended solids concentration (MLVSS), chemical oxygen demand (COD), ammonia nitrogen $\left(\mathrm{NH}_{3}-\mathrm{N}\right)$, $\mathrm{pH}$ value were conducted as described in standard methods ${ }^{11}$. The concentration of dissolved oxygen was determined by portable dissolved oxygen meter (HQ40d, HACH).

\section{RESULTS AND DISCUSSION}

Removal of $\mathrm{NH}_{3}-\mathrm{N}$ during continuous operation: The average influent $\mathrm{NH}_{3}-\mathrm{N}$ concentration was less than $50 \mathrm{mg} / \mathrm{L}$ during normal operating stage. In this study, the effectiveness of high concentration $\mathrm{NH}_{3}-\mathrm{N}$ degradation by $\mathrm{A} / \mathrm{O}$ process was evaluated. Ammonium sulfate was added to real petrochemical wastewater to increase the influent $\mathrm{NH}_{3}-\mathrm{N}$ concentration, the effect of sludge loading on removal of $\mathrm{NH}_{3}-\mathrm{N}$ was studied by changing the influent $\mathrm{NH}_{3}-\mathrm{N}$ concentration step by step from 20-105 mg/L. The removal rate of $\mathrm{NH}_{3}-\mathrm{N}$ during continuous operation is shown in Fig. 2.

Fig. 2 shows that the effluent $\mathrm{NH}_{3}-\mathrm{N}$ concentration was under $2 \mathrm{mg} / \mathrm{L}$ throughout the experiment, removal rate of $\mathrm{NH}_{3}-\mathrm{N}$

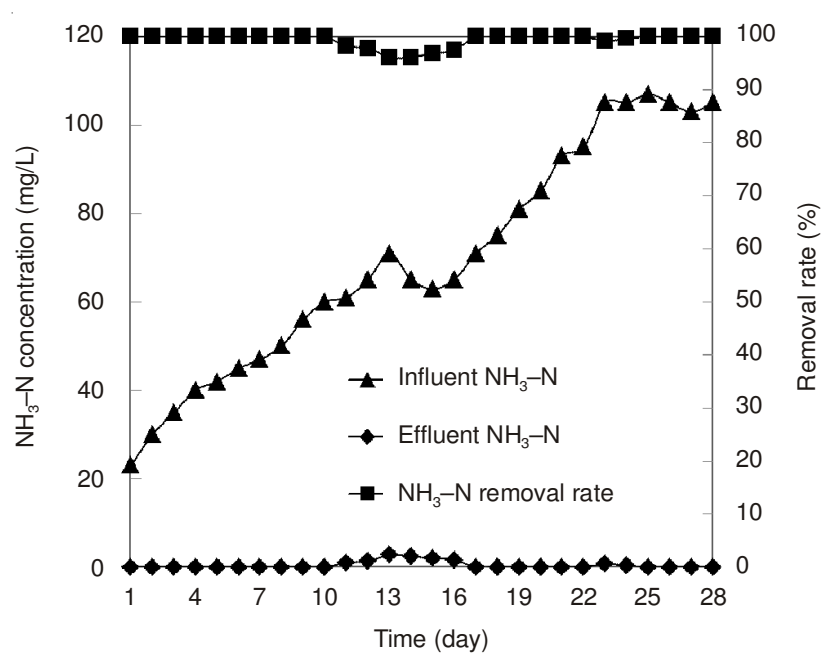

Fig. 2. Removal efficiency of $\mathrm{NH}_{3}-\mathrm{N}$ during continuous operation

was nearly $100 \%$ steadily, even when influent $\mathrm{NH}_{3}-\mathrm{N}$ concentration was up to $105 \mathrm{mg} / \mathrm{L}$. The $\mathrm{NH}_{3}-\mathrm{N}$ loading was low for the first 4 days, only about $0.002 \mathrm{kgNH}_{3}-\mathrm{N} /\left(\mathrm{m}^{3} \mathrm{~d}\right)$, then gradually increased to maximum $0.010 \mathrm{kgNH}_{3}-\mathrm{N} /(\mathrm{kgMLSS} \mathrm{d})$, compared with the design value of wastewater treatment plant (0.0029 $\mathrm{kg} \mathrm{NH}_{3}-\mathrm{N} /(\mathrm{kgMLSS} \mathrm{d})$ ), the experimental value increased by $245 \%$. The pilot experiment results indicated that the biosystem had a large load capacity, experimental data was the basis for overload operation of the wastewater treatment plant in the future.

Effect of $\mathbf{C} / \mathbf{N}$ ratio: Operational parameters affecting denitrification rate are diverse, such as $\mathrm{C} / \mathrm{N}$ ratio and $\mathrm{pH}$ value. In order to study the influence of $\mathrm{C} / \mathrm{N}$ ratio on removal rate of nitrogen in aerobic tank, $\mathrm{pH}$ value and $\mathrm{DO}$ concentration were maintained at 7.0-8.0 and $4 \mathrm{mg} / \mathrm{L}$, respectively. The original wastewater from the wastewater treatment plant was variable, influent $\mathrm{COD}$ and $\mathrm{NH}_{3}-\mathrm{N}$ were $198-350 \mathrm{mg} / \mathrm{L}, 35-70 \mathrm{mg} / \mathrm{L}$, respectively. The influent $\mathrm{COD} / \mathrm{N}$ ratio was modified by adding sucrose and ammonium sulfate to the original influent. Effulent $\mathrm{NH}_{3}-\mathrm{N}, \mathrm{NO}_{3}{ }^{-}-\mathrm{N}, \mathrm{NO}_{2}{ }^{-}-\mathrm{N}$ concentrations at different $\mathrm{C} / \mathrm{N}$ ratio condition in the pilot equpiment are shown in Fig. 3(a-b).

As $\mathrm{C} / \mathrm{N}$ ratio increased from 2 to 5 , effulent $\mathrm{NH}_{3}-\mathrm{N}$ decreased from $5.5 \mathrm{mg} / \mathrm{L}$ to lower than $2 \mathrm{mg} / \mathrm{L}, \mathrm{NH}_{3}-\mathrm{N}$ removal rate was up to $97.2 \%$. In the meanwhile, effluent $\mathrm{NO}_{3}{ }^{-}-\mathrm{N}$ decreased from 34.1 to $11.6 \mathrm{mg} / \mathrm{L}$. When $\mathrm{C} / \mathrm{N}$ ratio was higher than $7, \mathrm{NH}_{3}-\mathrm{N}$ removal rate was almost $100 \%$, effulent $\mathrm{NH}_{3}-$ $\mathrm{N}$ was below the detection limit, $\mathrm{NO}_{3}{ }^{-} \mathrm{N}$ was around $5, \mathrm{NO}_{2}{ }^{-}$ $-\mathrm{N}$ was only $0.01 \mathrm{mg} / \mathrm{L}$. The results indicated that $\mathrm{C} / \mathrm{N}$ ratio is one of the most critical parameters of the nitrification process, low $\mathrm{C} / \mathrm{N}$ ratio was inadequate for establishing an efficient $\mathrm{A} / \mathrm{O}$ process, because it directly influences the growth competition between autotrophic and heterotrophic microorganism populations ${ }^{12}$. In order to achieve good nitrogen removal effect in $\mathrm{A} / \mathrm{O}$ system, $\mathrm{C} / \mathrm{N}$ ratio should be higher than 5 , in case the nitrogen removal may be limited by the lack of available organic carbon.

Effect of $\mathbf{p H}$ value: The influent $\mathrm{COD}$ and $\mathrm{NH}_{3}-\mathrm{N}$ concentration was $300 \mathrm{mg} / \mathrm{L}, 30-70 \mathrm{mg} / \mathrm{L}$ during steady operation in the wastewater treatment plant. In order to investigate the effect of influent $\mathrm{pH}$ value on removal rate of $\mathrm{COD}$ and $\mathrm{NH}_{3}-\mathrm{N}$ with different initial influent concentrations, influent $\mathrm{pH}$ value was 


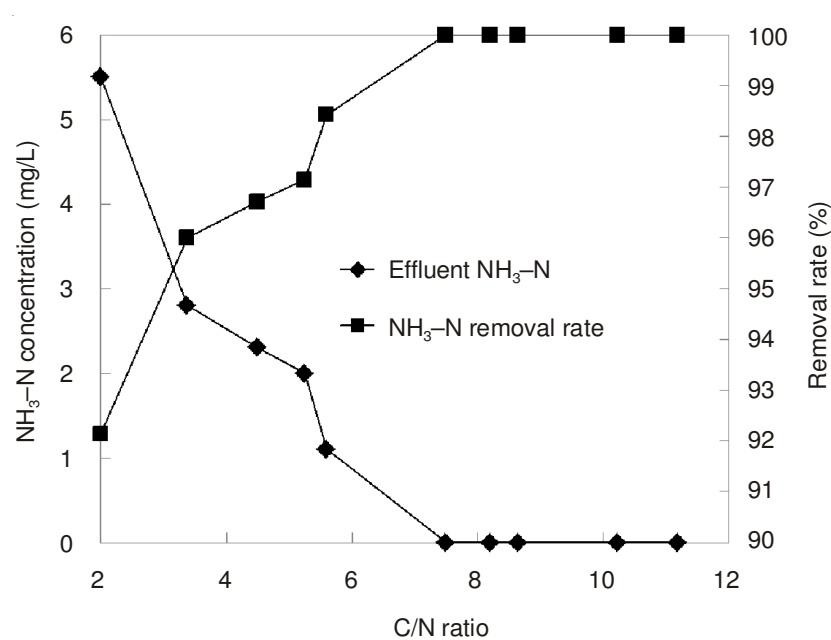

(a)

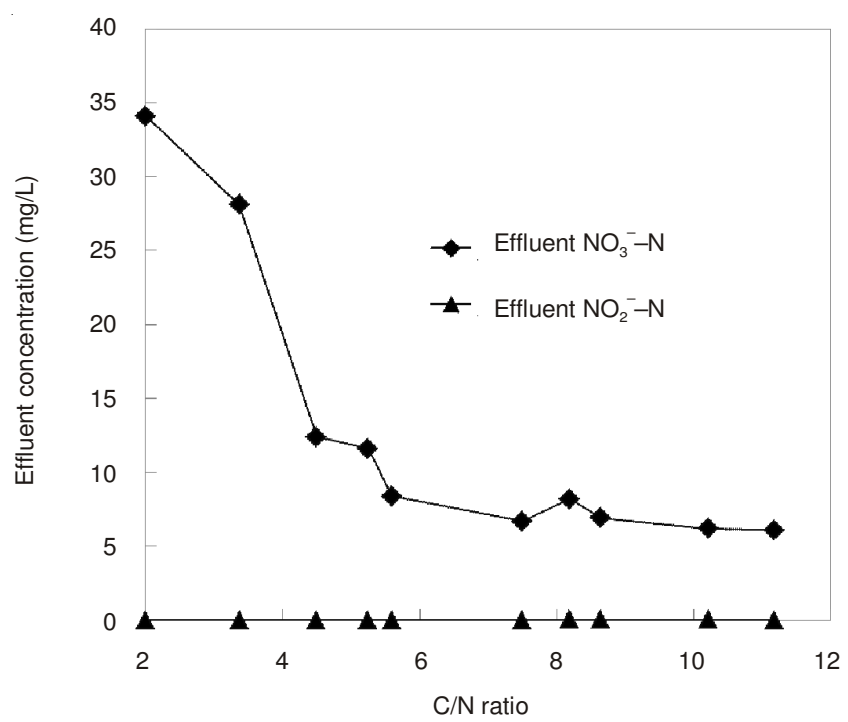

(b)

Fig. 3. Effect of $\mathrm{C} / \mathrm{N}$ ratio on effulent $\mathrm{NH}_{3}-\mathrm{N}, \mathrm{NO}_{3}{ }^{-}-\mathrm{N}$ and $\mathrm{NO}_{2}{ }^{-}-\mathrm{N}$

controlled at 5.0, 6.0, 7.0, 8.0, 9.0 and 10.0, respectively, influent COD was $300 \mathrm{mg} / \mathrm{L}$, influent $\mathrm{NH}_{3}-\mathrm{N}$ were 30,60 and $70 \mathrm{mg} / \mathrm{L}$.

Fig. 4 shows the changes of $\mathrm{COD}$ and removal rate of $\mathrm{NH}_{3}-\mathrm{N}$ at different $\mathrm{pH}$ condition. As shown in Fig. 4, removal rate of $\mathrm{COD}$ was fluctuant with the increase of $\mathrm{pH}$ value. In $\mathrm{pH}$ range of 5-6 and 8-10, removal rate of COD decreased with the increase of $\mathrm{pH}$ value. When $\mathrm{pH}$ value was between 7-8, the A/O system achieved the best COD removal performance. By contrast, removal rate of $\mathrm{NH}_{3}-\mathrm{N}$ was improved with the increase of $\mathrm{pH}$ value. Fig. 5 shows the effluent $\mathrm{NH}_{3}-\mathrm{N}$ and removal rate of $\mathrm{NH}_{3}-\mathrm{N}$ at $\mathrm{pH}$ value from 5-12.

In general, $\mathrm{pH}$ has a significant impact on nitrification efficiency ${ }^{13}$. As shown in Fig. 5, when $\mathrm{pH}$ value exceeded this range, nitrifiers activity decreased greatly after $\mathrm{pH}$ value was higher than 10 , because they were sensitive to variety of $\mathrm{pH}$, denitrification was restrained intensively and nitrate was accumulated at high $\mathrm{pH}$ condition. Therefore, appropriate $\mathrm{pH}$ can stimulate the denitrification process and keep high organic pollutant removal rate, the optimal $\mathrm{pH}$ value should be $7-8$.

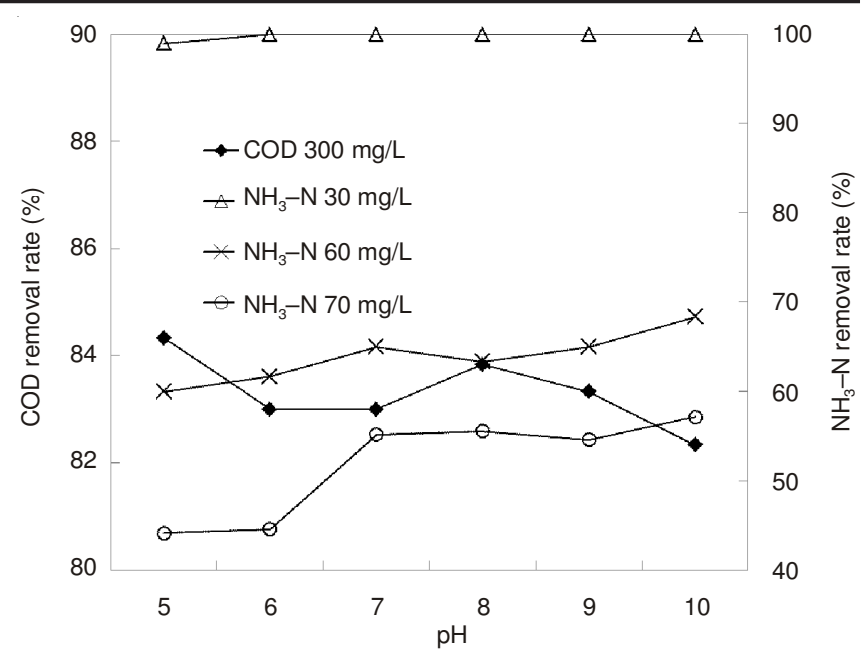

Fig. 4. Effect of $\mathrm{pH}$ on removal rate of $\mathrm{COD}$ and $\mathrm{NH}_{3}-\mathrm{N}$

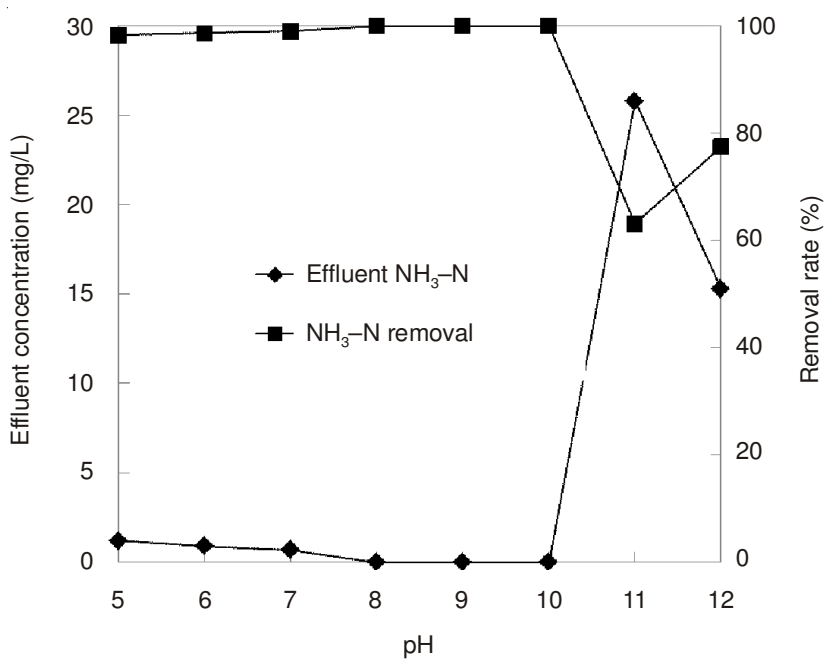

Fig. 5. Effluent $\mathrm{NH}_{3}-\mathrm{N}$ and removal rate at different $\mathrm{pH}$ condition

Denitrification kinetics: Study on substrate degradation and microbial proliferation kinetics of biosystem is meaningful to control and optimize the process of wastewater treatment. Biodegradation kinetics of wastewater is often expressed by the Monod equation ${ }^{14}$. A simplified model development was used to simulate the experimental results. The sludge denitrification kinetics could be described by Monod model:

$$
v=\frac{v_{\max } S}{K_{S}+S}
$$

where $\mathrm{S}$ is the nitrate concentration; $v$ is the denitrification rate; $v_{\max }$ is the maximum denitrification rate; $\mathrm{K}_{\mathrm{S}}$ is the Monod or half-saturation constant.

According to the physical meaning of the substrate degradation, the denitrification rate can be expressed as follows:

$$
v=-\frac{1}{X} \frac{d S}{d t}
$$

where $-\frac{\mathrm{dS}}{\mathrm{dt}}$ is the denitrification rate; $\mathrm{X}$ is the mixed liquor suspended solid concentration(MLSS).

Denitrification kinetics equation can be expressed according to eqns. 1 and 2: 


$$
-\frac{\mathrm{dS}}{\mathrm{dt}}=v_{\max } \frac{\mathrm{XS}}{\mathrm{K}_{\mathrm{S}}+\mathrm{S}}
$$

Monod equation can be simplified depending on different substrate concentrations. When $10 \mathrm{~K}_{\mathrm{S}}>\mathrm{S}>\mathrm{K}_{\mathrm{S}}$, simplified and linearized Monod equation can be used for describing the degradation kinetics of ammonia nitrogen by activated sludge. The fitting equation can be expressed as follows ${ }^{15}$ :

$$
\frac{1}{\mathrm{v}}=\frac{1}{\mathrm{v}_{\max }}+\frac{\mathrm{K}_{\mathrm{S}}}{\mathrm{v}_{\max }} \frac{1}{\mathrm{~S}}
$$

Drawing the relation curve of $1 / \mathrm{v}$ and $1 / \mathrm{S}$ can obtain the numerical value of $v_{\max }$ and $K_{S}$.

In this study, denitrification were investigated in aerobic tank of the pilot equipment. MLSS, $\mathrm{pH}$ and DO concentration in aerobic tank were maintained at $7000 \mathrm{mg} / \mathrm{L}, 7.0-8.0$ and 4 $\mathrm{mg} / \mathrm{L}$, respectively. The initial $\mathrm{NH}_{3}-\mathrm{N}$ concentration was 10 $\mathrm{mg} / \mathrm{L}$. Determined $\mathrm{NH}_{3}-\mathrm{N}$ concentration in aerobic tank every $2 \mathrm{~h}$, the curve of $\mathrm{NH}_{3}-\mathrm{N}$ degradation was shown as Fig. 6.

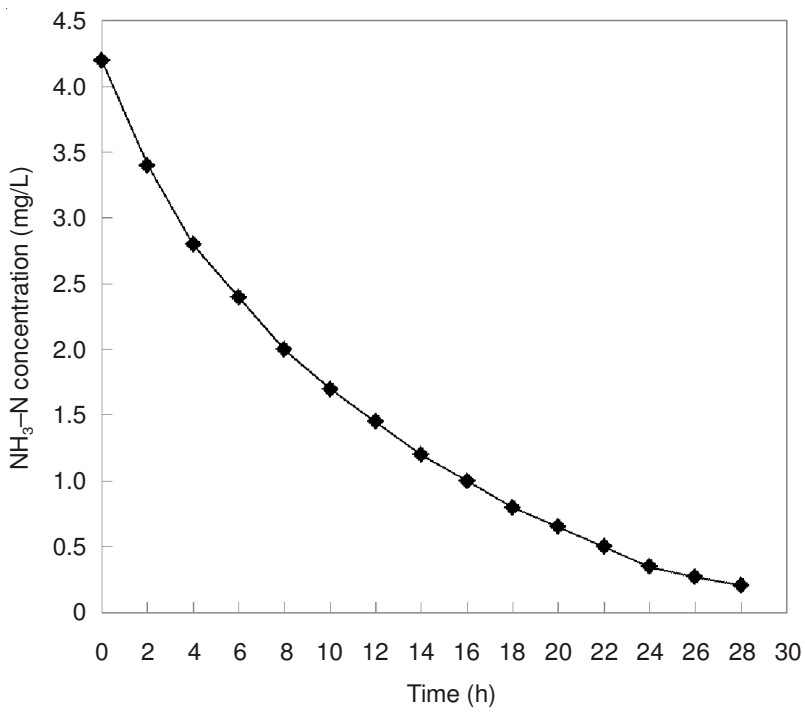

Fig. 6. Curve of $\mathrm{NH}_{3}-\mathrm{N}$ degradation

As shown in Fig. 6, $\mathrm{NH}_{3}-\mathrm{N}$ concentration was under 0.2 $\mathrm{mg} / \mathrm{L}$ after $28 \mathrm{~h}$, which means the degradation of $\mathrm{NH}_{3}-\mathrm{N}$ in aerobic tank was almost finished. Drawing the relation curve of $1 / \mathrm{v}$ and $1 / \mathrm{S}$, the fitting curve was shown in Fig. 7.

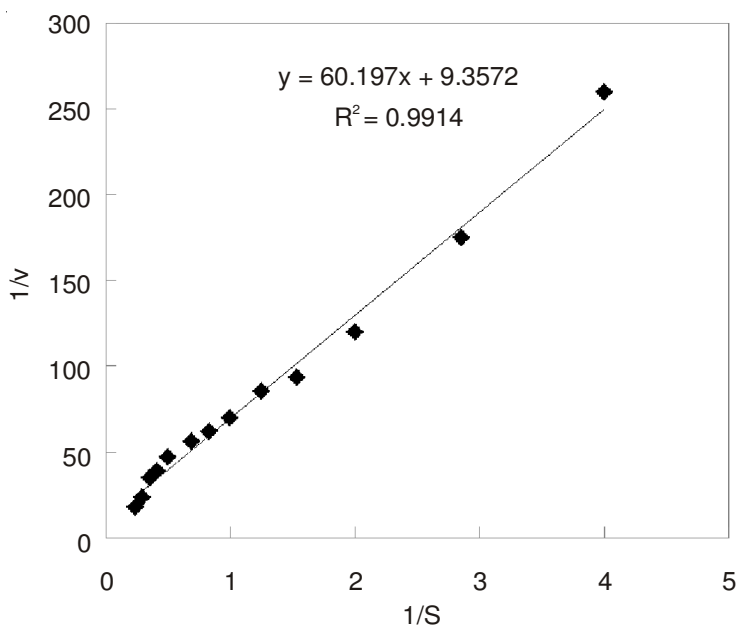

Fig. 7. Monod equation fitting curve
Correlation coefficient of Monod equation fitting curve was 0.9914 , according to the fitting equation, kinetics parameters of Monod equation can be calculated as: $v_{\max }=0.12 \mathrm{~h}^{-1}$, $\mathrm{K}_{\mathrm{S}}=7.22 \mathrm{mg} / \mathrm{L}$. The kinetic equation of $\mathrm{NH}_{3}-\mathrm{N}$ degradation by activated sludge can be expressed as:

$$
v=v_{\max } \frac{S}{K_{S}+S}=0.12 \times \frac{S}{7.22+S}
$$

\section{Conclusion}

Pilot experiment showed that anaerobic-aerobic (A/O) process was effictive to remove $\mathrm{NH}_{3}-\mathrm{N}$ from petrochemical wastewater. With the influent $\mathrm{NH}_{3}-\mathrm{N}$ concentration from 20 $105 \mathrm{mg} / \mathrm{L}$, effluent $\mathrm{NH}_{3}-\mathrm{N}$ was less than $2 \mathrm{mg} / \mathrm{L}, \mathrm{NH}_{3}-\mathrm{N}$ removal rate was almost $100 \%$. The maximum $\mathrm{NH}_{3}-\mathrm{N}$ loading was $0.010 \mathrm{kgNH}_{3}-\mathrm{N} /(\mathrm{kgMLSS} \mathrm{d})$. The experimental value increased by $245 \%$ compared with the design value of wastewater treatment plant.

$\mathrm{C} / \mathrm{N}$ ratio and $\mathrm{pH}$ value were the key factors on nitrogen removal effect in the biosystem. The optimal experiment conditions in pilot equipment were determined as follows: $\mathrm{C} / \mathrm{N}=5$, $\mathrm{pH}$ value 7.0-8.0. $\mathrm{NH}_{3}-\mathrm{N}$ biodegradation kinetics of wastewater can be expressed by the Monod equation. The kinetic parameters of $\mathrm{NH}_{3}-\mathrm{N}$ degradation were determined, where the maximum degradation rate was $0.12 \mathrm{~h}^{-1}$, half-saturation constant was $7.22 \mathrm{mg} / \mathrm{L}$.

\section{REFERENCES}

1. Y.J. Chan, M.F. Chong, C.L. Law and D.G. Hassell, Chem. Eng. J., 155, 1 (2009)

2. N. Alavi, R. Azadi, N. Jaafarzadeh and A.-A. Babaei, Asian J. Chem., 39, 2035 (2004).

3. M.S. Bilgili, A. Demir, E. Akkaya and B. Ozkaya, J. Hazard. Mater., 158, 157 (2008).

4. M. Selvamurugan, P. Doraisamy and M. Maheswari, Ecol. Eng., 36, 1686 (2010).

5. H. An, Y. Qian, X.S. Gu and W.Z. Tang, Chemosphere, 33, 2533 (1996).

6. S.P. Sun, C.P. Nacher, B. Merkey, Q. Zhou, S.-Q. Xia, D.-H. Yang, J.H. Sun and B.F. Smets, Environ. Eng. Sci., 27, 111 (2010).

7. J. Serralta, L. Borrás, C. Blanco, R. Barat and A. Seco, Water Sci. Technol., 50, 145 (2004).

8. D.W. Koren, W.D. Gould and P. Bedard, Hydrometallurgy, 56, 127 (2000).

9. M.I. Queiroz, E.J. Lopes, L.Q. Zepka, R.G. Bastos and R. Goldbeck, Bioresour. Technol., 98, 2163 (2007).

10. V. Parco, M. Wentzel and G. Ekama, Desalination, 199, 89 (2006).

11. APHA, AWWA, WEF: Standard Methods for the Examination of Water and Wastewater, Washington, edn. 20 (1999).

12. K. Bernat and I. Wojnowska-Baryla, Biochem. Eng. J., 36, 116 (2007).

13. A. Spagni, J. Buday, P. Ratini and G. Bortone, Water Sci. Technol., 43, 197 (2001).

14. Y. Yamada and Y. Kawase, Waste Manage., 26, 49 (2006).

15. F. Fang, Z.F. Jin and Z.Y. Pan, J. Zhejing Univ. Technol., 34, 381 (2006). 